\title{
Relationship Between Time of Ischemia and Global Longitudinal Strain of Left Ventricle in Patients with ST-Segment Elevation Myocardial Infarction who were Successfully Reperfused
}

\author{
Setiawan Widodo*, Hasanah Mumpuni, Nahar Taufiq
}

Department of Cardiology and Vascular Medicine, Faculty of Medicine, Public Health and Nursing, Universitas Gadjah Mada Dr. Sardjito Hospital, Yogyakarta, Indonesia

\section{ARTICLE INFO}

*Corresponding author

email:

stiawanwidodo@gmail.com

address:

Jalan Farmako Sekip Utara,

Yogyakarta, Indonesia

55281

Keywords:

acute myocardial infarction;

infarction area; global longitudinal strain

Manuscript submitted: November 5, 2019

Revised and accepted: May 10, 2020

\begin{abstract}
Background: Coronary heart disease (CHD) is a problem that contributes to morbidity and mortality. Acute myocardial infarction with ST-Segment Elevation Myocardial Infarction (STEMI) is the most common manifestation of CHD. Cardiac muscle damage caused by STEMI is dynamic. The longer coronary is occluded, the area of infarction will be greater than cause biomechanical changes in the myocardium. Speckle Tracking Echocardiography (STE) through a longitudinal strain parameter is a technique of assessing myocardial deformation and predicting the infarct area immediately after reperfusion therapy.

Method: This study was an analytic observational study with a cross-sectional method. Subjects were STEMI patients who were successfully reperfused and fulfilled the inclusion and exclusion criteria. Transthoracic echocardiography was performed within 12 hours after reperfusion. Strain analysis was done offline at the work station. A normality test was performed to determine the type of correlation test used. The influence of confounding factors was analyzed by bivariate and multivariate. A value of $p<0.05$ was said to be statistically significant.
\end{abstract}

Results: There were 43 subjects, ischemia time and global longitudinal starin (GLS) were obtained. A normality test using Shapiro Wilk revealed that data distribution of the two variables was abnormal. The Spearman correlation test was used to assess the relationship between the two variables and found a negative correlation between the time of ischemia and GLS ( $\mathrm{r}=-0.546 ; \mathrm{p}=0.000)$. Bivariate and multivariate analyses were performed to assess the influence of confounding factors. From the multivariate test, it was found that ischemia time was an independent factor influencing GLS value ( $\mathrm{p}=0.002)$.

Conclusion: There is a negative correlation between ischemia time and left ventricular GLS in STEMI patients who were successfully reperfused $(r=$ $-0.546 ; p=0.000$ ).

\section{INTISARI}

Latar Belakang: Penyakit jantung koroner (PJK) menjadi masalah yang berkontribusi terhadap angka kesakitan dan kematian. Infark miokard akut dengan ST-elevasi (IMA-EST) merupakan manifestasi utama PJK. Kerusakan otot jantung karena STEMI merupakan dinamis. Semakin lama koroner tersumbat, area kematian menjadi lebih besar dan menyebabkan perubahan biomekanik pada otot jantung. Speckle Tracking Echocardiography (STE) dengan parameter longitudinal strain adalah teknik untuk menilai deformasi otot jantung dan memprediksi area kematian segera setelah reperfusi. 


\begin{abstract}
Metode: Penelitian ini merupakan penelitian observasi analitik dengan metode potong lintang. Subjek adalah pasien STEMI yang menjalani reperfusi dengan sukses dan memenuhi kriteria inklusi dan eksklusi. Transthoracic echocardiography (TTE) dilakukan dalam 12 jam setelah reperfusi. Analisis strain dilakukan offline dengan work station. Uji normalitas dilakukan untuk menentukan tipe korelasi yang digunakan. Pengaruh faktor-faktor perancu dianalisis dengan analisis univariat dan multivariat. Nilai $<0.05$ ditentukan sebagai kebermaknaan statistik.
\end{abstract}

Hasil: Hasil penelitian didapatkan 43 subjek penelitian. Uji normalitas menggunakan Shapiro Wilk menunjukkan bahwa sebaran data kedua variabel tidak normal. Uji korelasi Spearman digunakan untuk menilai hubungan kedua variabel dan menemukan korelasi negatif antara waktu iskemia dan GLS $(r=-0,546 ; p=0,000)$. Analisis bivariat dan multivariat dilakukan untuk menilai pengaruh faktor perancu. Dari uji multivariat diketahui bahwa waktu iskemia merupakan faktor independen yang mempengaruhi nilai GLS ( $\mathrm{p}=0,002)$.

Kesimpulan: Ada hubungan negatif antara waktu iskemia dengan GLS ventrikel kiri pada pasien STEMI yang berhasil dilakukan reperfusi $(\mathrm{r}=$ $-0,546 ; p=0,000$ ).

\section{Introduction}

Coronary heart disease (CHD) is a matter of concern and contributes significantly to morbidity and mortality. ${ }^{1}$ Acute ST-segment elevation myocardial infarction (STEMI) as one manifestation of CHD is responsible for $25 \%-40 \%$ of the overall incidence of myocardial infarction. The incidence of hospitalization due to STEMI varies in different countries. In Sweden, there are 66 cases of STEMI / 100,000 people/year. Similar rates of incidence have also been reported in Belgium and the United States. Based on Rikerdas data in 2013, the prevalence of CHD in Indonesia in the age group $\geq 15$ years is $0.5 \%$ or estimated to be around 883,447 people, whereas based on doctor/symptom diagnosis is $1.5 \%$ or an estimated $2,650,340$ people. Data on the prevalence of CHD in the age group $\geq 15$ years based on doctor/symptom diagnosis in Yogyakarta Special Region in 2013 was $1.3 \%$ or estimated to be around 36,104 people. The rate of AMI treatment at CVCU Dr. Sardjito Hospital in 2017 was 74\% and $53 \%$ was STEMI. ${ }^{2,3,4}$

Cardiac muscle damage caused by STEMI is a series of time-dependent process. The duration of coronary occlusion will affect transmural damage and the extent of infarction which will directly determine remodeling and ventricular function. The reperfusion procedure by adhering to the principle of "minute means muscle" is intended to limit the extent of infarction. Therefore, quantification of infarction area measurement becomes one of the important things in the management of STEMI. Echocardiography speckle tracking (EST) is one way to assess myocardial deformation, ventricular function and predict infarction size immediately after reperfusion therapy on STEMI. $5,6,7,8$

Echocardiography Speckle Tracking can assess the deformation of the heart muscle during the cardiac cycle. Deformation is described in the form of longitudinal, radial and circumferential strains. Longitudinal strains (Global longitudinal strains / GLS) are one of the parameters of EST that can be used to assess infarction area. ${ }^{9,10}$ This study aims to assess whether there is a relationship between the time of ischemia and GLS in patients with STEMI who successfully performed reperfusion at RSUP Dr. Sardjito Yogyakarta.

\section{Methods}

This research is an analytic observational study with the cross-sectional method. The data were taken in the form of primary data in the form of clinical data, reperfusion therapy data and echocardiographic data in patients with STEMI in RSUP Dr. Sardjito Yogyakarta. Subjects were patients diagnosed as STEMI who were successfully reperfused. Inclusion criterion is a first-time patient diagnosed with STEMI according to the STEMI diagnostic criteria of ESC/AHA, with 1) age of 18 to 75 years, 2) underwent reperfusion with fibrinolytic or primary or rescue PCI at Dr. RSUP. Sardjito and was declared successful. Exclusion criteria include: 1) History of previous CHD, 2) History of previous heart attacks, 3) History of heart failure, 4) Significant left heart valve disease, 5) Pacing rhythms 6) Cardiogenic shock, 7) Can not be examined for ventricular strains. The research subjects were sampled using consecutive sampling method.

Reperfusion was carried out following procedures at the Dr. RSUP Sardjito Yogyakarta. Ischemia time is calculated in minutes. Transthoracic echocardiography was performed during treatment at CVCU within 12 hours post-reperfusion using the VIVID S6 machine (General Electric, USA). Two-dimensional echocardiographic data is sent to the work station computer for analysis offline. Strains are assessed in the apical 4-chamber, apical 3-chamber, and apical 2-chamber positions. Strain analysis was carried out intra-observers and inter-observers by 2 expert examiners who were blinded to the subject's clinical data, which had previously been measured for Cohen's kappa $(\mathrm{K})$ values. 
Statistical analysis uses Statistical Package for Social Sciences (SPSS) software version 23 for the Windows operating system. The correlation test between two numerical variables is assessed using the Pearson test if the data is normally distributed or the Spearman test if the data is not normally distributed. The influence of confounding factors will be analyzed bivariate, for categorical data types an independent t-test will be conducted while the numerical data will be performed Pearson correlation test if the data is normally distributed or the Spearman test if the data is not normally distributed. Bivariate analysis of significant numerical data $(\mathrm{p}<0.25)$ will then be continued with a multivariate linear regression analysis test. The results have significant value if $\mathrm{p}<0.05$. Confounding factors with categorical data types were not carried out the multivariate analysis, the results of the bivariate analysis of categorical data were significant $(p<0.05)$ indicating that confounding factors significantly affected the GLS value.

\section{Results}

The study began from 23 May 2019 to 15 July 2019. During this period, a total of 90 STEMI patients were admitted from the emergency room and treated at ICCU Dr. Sardjito General Hospital Yogyakarta. Of the total 90 patients, 55 patients underwent primary PCI, 4 patients received fibrinolytic therapy, 5 patients underwent rescue PCI due to failure of fibrinolysis, 13 patients underwent routine angiography and 13 patients received conservative therapy. Patients who only undergo routine angiography are caused because when the patient arrives at the emergency department the patient is in a stable hemodynamic condition, no ST-segment elevation is obtained and the patient has not complained of chest pain. Some patients only receive conservative therapy including due to consideration of age and comorbid diseases, insurance coverage problems, onset $>48$ hours with stable hemodynamic and pain-free.

A total of 64 patients who underwent reperfusion consisted of 55 primary PCI, 4 patients underwent fibrinolysis and 5 patients underwent rescue PCI. A total of 23 patients were excluded, where 1 patient was due to a history of previous coronary heart disease, 6 patients had cardiogenic shock and needed inotropic or vasopressors, 2 patients due to fibrinolysis therapy in the previous hospital, 2 patients were declared unsuccessful for reperfusion because angiography obtained flow TIMI 2, 6 patients could not be analyzed because of poor echo window and 6 patients aged over 75 years. The total subject that fulfilled the criteria were 47 subjects (figure 1).

The basic characteristics of the research subjects can be seen in table 1 . In this study, the subjects were males (39 $(90.69 \%)$ and females $4(9.31 \%)$ with a mean age of 55.54 \pm 8.69 years. Subjects with risk factors for diabetes mellitus were 13 (30.23\%), hypertension 23 (53.49\%), dyslipidemia 3 (6.98\%), and smoking/smoking history as many as $31(72.09 \%)$ subjects. The presentation of blood sugar when the subject came to the Dr. Sardjito General Hospital was $189.49 \pm 84.12 \mathrm{mg} / \mathrm{dl}$. Echocardiographic examination results showed an average ejection fraction of $48.35 \pm 9.38 \%$ and a median GLS value of $-10.1 \%$ (maximum range: $-13.7--12.2 \%$ ). While the laboratory parameters obtained a median high sensitivity Troponin I (Hs-Troponin I) of $5864 \mathrm{ng} / \mathrm{L}$ (minimum-maximum range: 64.9-4000 ng/L).

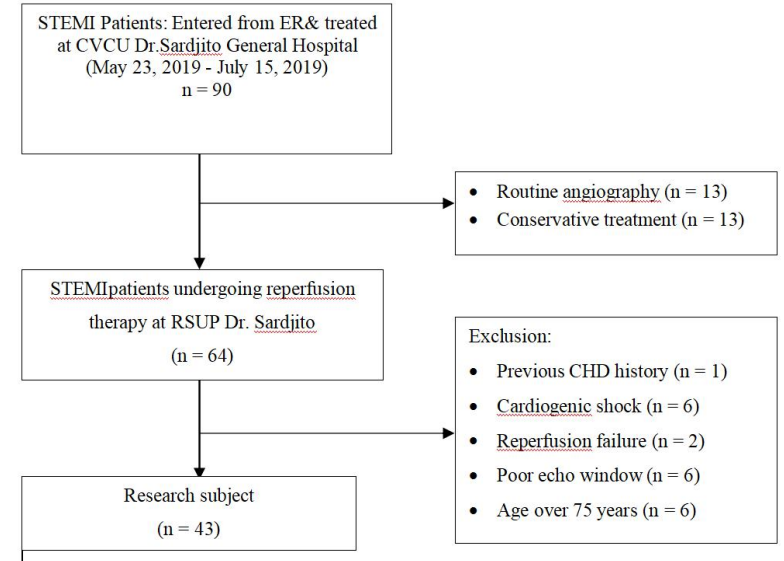

Figure 1. The flowchart of recruitment research subjects

STEMI patients who came to the ER had a median time of onset of 420 minutes (range: 60-4320 minutes). The median time since the patient was diagnosed with STEMI in the ER until primary PCI and 153 minutes rescue PCI (range: 45-490 minutes). While the meantime of patients diagnosed with STEMI to get lytic bolus was $66 \pm 23.02$ minutes. The overall ischemia time is the time calculated from the onset of typical chest pain felt until the patient is diagnosed with STEMI at Dr.Sardjito General Hospital and is augmented by intestinal lytic bolus time or crossing wire time, reaching $805.12 \pm 765.11$ minutes.

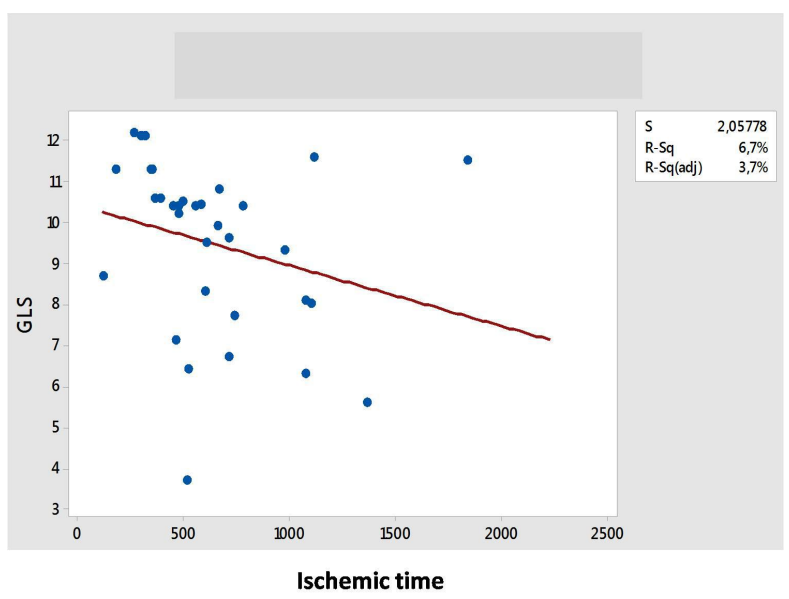

Figure 2. Scatter-plot relationship between ischemia time (min) and GLS (\%) values in STEMI patients who successfully reperfused $(r=-0.546 ; p=0.000)$

Test the normality of data with the Shapiro-Wilk test on the ischemia time variable and GLS where the test results indicate the two parameters are not normally distributed $(p=0,000 ; p=0.004)$. Correlation analysis of the two variables with the Spearman test, and found a negative 
relationship between the two variables with a moderate and statistically significant relationship strength $(\mathrm{r}=-0.546$ and $\mathrm{p}=0.000$ ).

Table 1.

Basic Characteristics of Research Subjects

\begin{tabular}{|c|c|}
\hline Variable & Sum $(n=43)$ \\
\hline \multicolumn{2}{|l|}{ Gender : } \\
\hline Male; n (\%) & $39(90.69)$ \\
\hline Female; n (\%) & $4(9.31)$ \\
\hline Age (y.o); mean $\pm S D$ & $55.54 \pm 8.69$ \\
\hline Blood glucose; median (min-max) & $166(88-448)$ \\
\hline \multicolumn{2}{|l|}{ Risk factor : } \\
\hline Diabetes Mellitus; n (\%) & $13(30.23)$ \\
\hline Hipertension; n (\%) & $23(53.49)$ \\
\hline Dyslipidemia; n (\%) & $3(6.98)$ \\
\hline Smoking; n (\%) & 31 (72.09) \\
\hline \multicolumn{2}{|l|}{$\begin{array}{l}\text { Therapy before echocardiographic } \\
\text { examination }\end{array}$} \\
\hline ACEI/ARB; n (\%) & $22(51.16)$ \\
\hline Beta-blocker; n (\%) & $9(20.93)$ \\
\hline Nitrate; n (\%) & $7(16.28)$ \\
\hline Statin; n (\%) & $43(100)$ \\
\hline Antiplatelet; n (\%) & $43(100)$ \\
\hline Anticoagulant; n (\%) & $18(41.86)$ \\
\hline \multicolumn{2}{|l|}{ Reperfusion : } \\
\hline Fibrynolitic; n (\%) & $4(9.31)$ \\
\hline Primary PCI; n (\%) & 34 (79.07) \\
\hline Rescue PCI; n (\%) & $5(11.62)$ \\
\hline \multicolumn{2}{|l|}{ Time Parameter : } \\
\hline Onset (minutes)*; median (min-max) & $420(60-4320)$ \\
\hline $\begin{array}{l}\text { Crossing wire (minutes) }{ }^{* *} \text {; median } \\
\text { (min-max) }\end{array}$ & $153(45-490)$ \\
\hline Lytic bolus(minutes) ${ }^{* * *} ;$ mean \pm SD & $66 \pm 23,02$ \\
\hline $\begin{array}{l}\text { Ischemia time (minutes) }{ }^{* * * *} \text {; median } \\
\text { (min-max) }\end{array}$ & $602(120-4651)$ \\
\hline \multicolumn{2}{|l|}{ Echocardiographic parameter : } \\
\hline Ejection fraction; mean $\pm S D$ & $48.35 \pm 9.38$ \\
\hline GLS; median (min-max) & $-10.1(-3.7--12.2)$ \\
\hline \multicolumn{2}{|l|}{ Laboratory parameter } \\
\hline Hs-Troponin I (ng/L); median (min-max) & $5864(64.9-4000)$ \\
\hline
\end{tabular}

STEMI: acute myocardial infarction with ST-segment elevation; ACEI: angiotensin-converting enzyme inhibitor; ARB: angiotensin receptor blockers; GLS: Global longitudinal strains; SD: standard deviation; min: minimum; max: maximum.

* Onset: the time from the onset of typical angina symptoms to the diagnosis of STEMI;

** Wire crossing time: the time from the patient's diagnosis of STEMI to the wire crossing of lesions in infarct-related arteries during the primary IKP procedure.

*** Lytic bolus time: the time from the patient's diagnosis of STEMI to the first drops of fibrinolysis agent in the fibrinolysis procedure.

**** Ischemia time: the time calculated from the onset of typical chest pain felt until the patient is diagnosed with STEMI plus the intravenous bolus lytic time or crossing wire time

Bivariate analysis with the Spearman correlation test to analyze confounding factors with numerical variable types, while analysis with an independent t-test was conducted to analyze confounding factors with categorical data types. The bivariate test results of the confounding variables which are estimated to influence the GLS value can be seen in table 2 .
Table 2.

Bivariate Analysis of Factors Associated with GLS Value in STEMI Patients Successfully Repeated

\begin{tabular}{ll}
\hline Variables & P value \\
\hline Age* & $0.107^{* * *}$ \\
Blood glucose* & 0.339 \\
Ischemia time* & $0.001^{* * *}$ \\
Diabetes Melitus & 0.163 \\
Hipertension** & 0.801 \\
Smoking** & 0.232 \\
ACEI/ARB** & 0.637 \\
Beta-blocker** & 0.746 \\
Nitrate** & 0.157 \\
Anticoagulant** & 0.882 \\
\hline ACEI: angiotensin-converting-enzyme inhibitor; ARB: angiotensin \\
receptor blockers. \\
* Confounding factors in the form of numerical data are tested \\
with Spearman correlation \\
** Confounding factors in the form of categorical data were tested \\
by independent t-test, significant $(\mathrm{p}<0.05)$ \\
*** Bivariate analysis of numerically significant variables $(\mathrm{p}<0.25)$ \\
will be continued with multivariate analysis of linear regression
\end{tabular}

Confounding variables with $\mathrm{p}$ values $<0.25$ were then subjected to multivariate linear regression analysis (Table 3). From the multivariate analysis, it was found that ischemia time was an independent variable related to changes in GLS ( $p=0.002)$.

Table 3.

Multivariate Analysis of Factors Associated with Changes in GLS Values in STEMI Successfully Reproduced

\begin{tabular}{ll}
\hline Variables & P value \\
\hline Age & 0.203 \\
Ischemia time & $0.002^{* *}$ \\
\hline
\end{tabular}

* Time of ischemia: the time calculated from the onset of typical chest pain felt until the patient is diagnosed with STEMI plus the time interval of bolus lytic or time of crossing wire ** Significant multivariate analysis value $(\mathrm{p}<0.05)$

\section{Discussion}

In this study, the mean age of study subjects was $55.54 \pm$ 8.69 years with the proportion of male sex as many as 39 $(90.69 \%)$ subjects. This data is following epidemiological data where the incidence of acute coronary syndrome is 3-4 times more frequent in men than women under the age of 60 years, but at the age of 75 years, the incidence of the acute coronary syndrome is more dominated by women. ${ }^{11}$ The epidemiology of STEMI patients in this study is also similar to the epidemiology of STEMI patients in Nepal reported by Adhikari and Baral $^{12}$ where the incidence of STEMI is high in men (87.66\%) at ages 50 years to 60 years. Similar to the study, Dharma et al. ${ }^{13}$ through the Jakarta Acute Coronary Syndrome Registry in 2008-2009 stated that the average age of patients experiencing STEMI was 55 years and $88 \%$ of them were male.

This study shows that smoking is the most traditional cardiovascular risk factor, which is 31 (72.09\%), followed by hypertension 23 (53.49\%), diabetes mellitus 13 $(30.23 \%)$ and dyslipidemia $3(6,98 \%)$ subject. The existence of these traditional risk factors will increase the 
risk of cardiovascular events where various studies have reported a strong relationship between cigarette smoke exposure and heart disease. The Framingham heart study also shows that the higher the cholesterol level, the greater the risk of CHD. The study also mentions that pre-hypertensive blood pressure increases the risk of cardiovascular disease twice. Other studies have shown that patients with diabetes mellitus are 2-8 times more likely to experience future cardiovascular events. ${ }^{14}$

In this study, the number of subjects who had received ACE inhibitors or ARBs before echocardiographic examination was 22 (51.16\%), who had received beta-blocker therapy as many as 9 (20.93\%), nitrate therapy as much as 7 (16.28) \%) and anticoagulant therapy in $18(41.86 \%)$ subjects. All subjects had received dual antiplatelet therapy and statins before the echocardiographic examination.

From this study, it was found that the median onset of symptoms of patients with STEMI who successfully performed reperfusion at RSUP dr. Sardjito is 420 minutes (minimum-maximum range: 60-4320 minutes), the median time since the patient was diagnosed with STEMI at the ER General Hospital Dr. Sardjito until crossing wire is 153 minutes (minimum-maximum range: 45-490 minutes) and the average lytic bolus is $66 \pm 23.02$ minutes. The overall median time of ischemia, that is, the time calculated from the onset of typical chest pain felt until the patient is diagnosed with STEMI plus the intrusive bolus lytic time or crossing wire time reaches 602 minutes (minimum-maximum range: 120-4561 minutes). Research by Salhpour et al. ${ }^{15}$ states that the time of ischemia is a better predictor than the door to balloon time in determining infarction area and mortality within 30 days post-STEMI. Francone et al. ${ }^{16}$ also mentioned that reperfusion time is a determinant of ischemic reversibility of myocardium. Reperfusion after 90 minutes of coronary occlusion is only able to save a small amount of myocardium that ischemic. Similar to the above studies, several studies also mentioned that the delay in reperfusion would be related to the extent of infarction, higher mortality and the frequency of higher treatment rates caused by heart failure, arrhythmias and the incidence of reinfarction. ${ }^{17,18,19,20}$

Correlation analysis between ischemia time and GLS values using the Spearman test found a negative relationship between the two statistically significant variables $(r=-0.546 ; p=0.000)$. In this study, the relationship between time of ischemia and GLS values has moderate (moderate) strength, characterized by the correlation coefficient ( $r$ ) of the Spearman test which is in the range of $0.41-0.60$. The results of this study are consistent with research by Francone et al. ${ }^{16}$ which states that reperfusion time is a determinant of the extent of infarction and the amount of myocardium that can be saved. Similar studies by Bertini et al. ${ }^{21}$ concluded that the longer ischemia time would cause a decrease in GLS values. Research by Sjoli et al. and a specificity of $91 \%$. Other studies state that the GLS value is less than $-15 \%$
post-STEMI as a predictor of the incidence of left ventricular remodeling. ${ }^{23}$

Based on the results of this study, the results show that every 60 minutes of reperfusion delay will reduce the GLS parameter by $1 \%$. The results of this study are in line with the results of a study by De Luca et al. ${ }^{18}$ which states that reperfusion time is linearly related to the area of infarction where the area of infarction will increase by $0.9 \%$ every 1 hour of reperfusion delay.

From a multivariate analysis, it was found that age is not an independent variable that can affect GLS values. Previous research by $\mathrm{Zghal}^{24}$ that aged over 75 years would reduce the value of GLS and there were this study subjects with age 75 years were excluded. Diabetes mellitus and GLS values did not correlate significantly with GLS. Other literature states that acute hyperglycemia will affect the extent of infarction. ${ }^{25}$ Cruz-Gonzales et al. ${ }^{26}$ also mentioned that the condition of hyperglycemia during the acute phase of STEMI is related to the extent of infarction if the level of hyperglycemia is above $11 \mathrm{mmol} /$ $\mathrm{L}$ or $200 \mathrm{mg} / \mathrm{dl}$. In contrast to previous studies, in this study blood sugar when not being an independent predictor of GLS values was possible because the mean blood sugar during hyperglycemia was $189 \mathrm{mg} / \mathrm{dl}$. Hypertension does not affect GLS values. Research by De Luca et al. ${ }^{18}$ and Reinstadler et al. ${ }^{27}$ in STEMI patients undergoing primary PCI, concluded that hypertension did not affect the efficacy of reperfusion, extent of infarction and reperfusion injury.

The results of the bivariate analysis found that smoking is not an independent variable that can effect changes in GLS. Research conducted by De Luca et al. ${ }^{18}$ stated that smoking does not affect the area of infarction. Another study by Giustino et al. ${ }^{28}$ also mentioned that smoking did not significantly affect the area of infarction after STEMI.

From this study, it was found that nitrate is not an independent variable that can affect GLS. Research by Jugdutt ${ }^{29}$ mentions that initial nitroglycerin administration (less than 4 hours onset) and given within an average of 10 to 12 hours from new-onset will be able to minimize the area of infarction. Ambrosio et $a .^{30}$ stated that the area of infarction in the chronic nitrate group was smaller than the naive nitrate group.

The results of the confounding factor analysis showed that there was no relationship between ACEI / ARB, beta-blockers and anticoagulant to GLS. In contrast to the results of this study, Bussmann et al. ${ }^{31}$ giving intravenous captopril at a dose of 1.5 to $2 \mathrm{mg} /$ hour for 18 hours were able to limit the extent of infarction. In this study, the administration of ACEI or ARB did not affect GLS values may be because subjects who received the therapy had a long ischemia time and patients who had just received 1 dose of ACEI or ARB and with inadequate doses. Likewise, the administration of beta-blockers in this study did not affect GLS. This result is supported by research by Ibanez et al. ${ }^{11}$ stating that the administration of metoprolol intravenously before reperfusion can reduce the area of infarction and damage to the myocardium/ejection 
fraction. In this study anticoagulant administration also did not significantly influence GLS. Similar to the results of this study, Song et al. $^{32}$ mentioned that anticoagulant administration after the successful Primary PCI did not provide benefits either in the improvement of ventricular function or remission of left ventricular.

From a multivariate analysis, it is known that the variable that can independently affect the GLS value is the time of ischemia. This can be explained because the total occlusion of the coronary arteries in STEMI will interfere with myocardial perfusion so that it will cause necrosis of myocardial cells. This process will interfere with myocardial biomechanical changes. ${ }^{33}$ Impaired myocardial perfusion will first interfere with the endocardial layer so that longitudinal strains will be the earliest parameters that are disturbed. Therefore GLS can be a broad predictor of infarction in STEMI patients. ${ }^{34}$

The limitation of this study, time ischemia becomes an independent variable determining the value of GLS, so the duration from coronary occlusion to reperfusion becomes an important determinant of muscle damage that will affect GLS values. In this study, the onset of arterial occlusion is difficult to determine precisely. The relationship between the two parameters may still be influenced by the amount of coronary artery occlusion, the degree of occlusion and the presence of coronary collateral flow, in which in this study the data were not analyzed as a factor affecting GLS values.

\section{Conclusion}

There is a significant negative relationship between ischemia time and GLS values measured by the speckle tracking echocardiography method in STEMI patients who successfully reperfused.

\section{References}

1. Abreu D, Cabral MS, Ribeiro F. 2014. Factors associated with longer delays in reperfusion in ST-segment elevation myocardial infarction. IJC Heart \& Vessels, 4:97-101.

2. O' Gara PT, Kushner FG, Ascheim DD, Casey DE, Chung MK, de Lemos JA, et al. 2013. ACCF / AHA Guideline 2013 ACCF / AHA Guideline for the management of ST-elevation myocardial infarction a report of the American College of Cardiology Foundation / American Heart Association task force on practice guidelines. Circulation, 27:e362-e425.

3. Steg G, James SK, Atar D, Badano LP, Borger MA, Di Mario C, et al. 2012. Guidelines for the management of acute myocardial infarction in patients presenting with ST-segment elevation. Eur Heart J, 33:2569-2619.

4. Hidayati F, Huda RF, Bagaswoto HP, Taufiq N, Setianto BY. 2017. Patient's profile across our intensive cardiac care unit: a single-center study at Sardjito hospital. Acta Cardiol Indones, 1: S22
5. Kumar VA, Fausto N. 2009. Robbins \& Cotran Pathologic Basis of Disease. 8th ed. WB Saunders, Philadelphia. USA

6. Mann LD, Zipes DP, Libby P, Bonow RO. 2015. Braunwald'S Heart disease A textbook of Cardiovascular Medicine. Elsevier, Philadelphia, UK.

7. Alishahi A, Carolina N, Hill C, Sciences M, Carolina N, Hill C, et al. 2014. Factors associated with delay in thrombolytic therapy in patients with ST-elevation myocardial infarction. J Teh Univ Heart Ctr, 7:65-71.

8. Islam AM. 2015. Ischemic time, infarct size and transmurality in acute ST-elevation myocardial infarction. Med J DY Patil Univ, 8:706-707.

9. Doğan C, Bayram Z, Candan Ö, Omaygenç O, Yılmaz F, Acaret RD, et al. 2017. Prediction of infarct size using two-dimensional speckle tracking echocardiography in acute myocardial infarction. Echocardiography, 34:376-382.

10. Munk K, Andersen NH, Nielsen SS, Bibby BM, Bøtker HE, Nielsen TT, et al. 2011. Global longitudinal strain by speckle tracking for infarct size estimation. Eur J Echocardiogr, 12:156-165.

11. Ibanez B, James S, Agewall S, Antunes MJ, Bucciarelli-Ducci C, Bueno H et al. 2017. Guidelines for the management of acute myocardial infarction in patients presenting with ST -segment elevation. The Task Force for the management of acute myocardial infarction in patients presenting with ST-segment elevation of the European Socie. Eur J Emerg Med, 39:119-177.

12. Adhikari G, Baral D. 2018. Clinical profile of patients presenting with acute myocardial infarction. Int J Adv Med, 5:228-233.

13. Dharma S, Andriantoro H, Purnawan I, Dakota I, Basalamah F, Hartono B, et al. 2016. Characteristics, treatment and in-hospital outcomes of patients with STEMI in a metropolitan area of a developing country: an initial report of the extended Jakarta Acute Coronary Syndrome registry. BMJ Open, 6:e012193.

14. Boudi FB, Ahsan CH, Ali YS, Compton SJ, Talavera F. 2016. Risk factors for coronary artery disease. Available at https://emedicine.medscape.com/ article/ 164163-overview.

15. Solhpour A, Chang K, Arain SA, Balan P, Loghin C, Mccarthy JJ, et al. 2016. Ischemic time is a better predictor than door-to-balloon time for mortality and infarct size in ST-Elevation myocardial infarction. Catheter Cardiovasc Interv, 87:1194-1200

16. Francone M, Buciarelli-Ducci C, Carbone I, Canali E, Scardala R, Calabrese F, et al. 2009. Impact of primary coronary angioplasty delay on myocardial salvage, infarct size, and microvascular damage in patients with ST-Segment elevation myocardial infarction. J Am Coll Cardiol, 54:2145-2153. 
17. Guerchicoff A, Brener SJ, Maehara AK, Witzenbliche B, Fahy M, Gersh BJ, et al. 2014. Impact of delay to reperfusion on reperfusion success, infarct size, and clinical outcomes in patients with ST-segment elevation myocardial infarction. J Am Coll Cardiol Intv, 7:733-740.

18. Luca GD, Suryapranata H, Ottervanger JP, Antman EM. 2004. Time delay to treatment and mortality in primary angioplasty for acute myocardial infarction every minute of delay counts. Circulation,109:1223-1225.

19. Lubovich A, Radzishevsky E, Goldenberg I, Matezky S, Rosenschein U. 2018. Total ischemic time and short, intermediate and long term mortality of patients with STEMI treated by primary percutaneous coronary intervention : Analysis of data from 2004 2013 ACSIS registry. J Integr Cardiol,4:1-4.

20. Stone GW, Selker HP, Thiele H, Patel MR, Udelson JE, Ohman EM, et al. 2016. Relationship between infarct size and outcomes following primary PCI. J Am Coll Cardiol, 67:1674-1683.

21. Bertini $\mathrm{M}$, Mollema SA, Delgado V, Antoni ML, Ng ACT, Holman ER, et al. 2020. Impact of time to reperfusion after acute myocardial infarction on myocardial damage assessed by left ventricular longitudinal strain. Am J Cardiol, 104:480-485.

22. Sjøli B, Ørn S, Grenne B, Ihlen H, Edvardsen T, Brunvand H. 2009. Diagnostic capability and reproducibility of strain by doppler and by speckle tracking in patients with acute myocardial infarction. JACC : Cardiovascular imaging, 2:24-33.

23. Joyce E, Hoogslag GE, Leong DP, Debonnaire P, Katsanos S, Delgado V. 2013. Association between left ventricular global longitudinal strain and adverse left ventricular dilatation after. Circ Cardiovasc Imaging, 7:74-81.

24. Zghal F, Bougteb H, Patricia R, Roudaut R. 2011. Assessing global and regional left ventricular myocardial function in elderly patients using the bidimensional strain method population. Echocardiography, 28:978-982.

25. Teraguchi I, Imanishi $\mathrm{T}$, Ozaki $\mathrm{Y}$, Tanimoto $\mathrm{T}$, Ueyama M, Orii M, et al. 2014. Acute-phase glucose fluctuation is negatively correlated with myocardial salvage after acute myocardial infarction. Circ J, 78:170-179.

26. Cruz-gonzalez I, Chia S, Raffel OC, Sanchez-ledesma M, Senatore F, Wackers FJ, et al. 2010. Hyperglycemia on admission predicts larger infarct size in patients undergoing percutaneous coronary intervention for acute ST-segment elevation myocardial infarction. Diabetes Res Clin Pract, 88:97-102.

27. Reinstadler SJ, Stiermaier T, Eitel C, Saad M, Metzler B, de Waha S, et al. 2016. Antecedent hypertension and myocardial injury in patients with reperfused STelevation myocardial infarction. J Cardiovasc Magn Reson, 18:80.

28. Giustino G, Brener SJ, Redfors B, Kirtane AJ, Genereux PG, Maehara A, et al. 2016. Effect of smoking on infarct size and major adverse cardiac events in patients with large anterior st-elevation myocardial infarction (from the INFUSE-AMI Trial). Am J Cardiol, 118:1097-1104

29. Judgutt BI. 1994. Nitrates in myocardial infarction. Cardiovasc Drugs Ther, 8:635-646.

30. Ambrosio G, Pinto MD, Tritto I, Agnelli G, Bentivoglio $\mathrm{M}$, Zuchi C, et al. 2010. Chronic nitrate therapy is associated with different presentation and evolution of acute coronary syndromes: insights from 52693 patients in the Global Registry of Acute Coronary Events. Eur Heart J, 31:430-438.

31. Bussmann WD, Micke G, Hildenbrand R, Klepzig H. 1995. Captopril in acute myocardial infarction: beneficial effects on infarct size and arrhythmia. Clin Cardiol, 18:465-470.

32. Song J, Zhu L, Lee C, Ren H, Cao C, Chen H. 2016. Total ischemic time and outcomes for patients with ST-elevation myocardial infarction: does time of admission make a difference?. J Geriatr Cardiol,13:658-664.

33. Voorhees AP, Han H. 2016. Biomechanics of cardiac function. Compr Physiol, 5:1623-1644.

34. Bière L, Donal E, Terrien G, Kervio G, Willoteaux S, Furber A, et al. 2014. Longitudinal strain is a marker of microvascular obstruction and infarct size in patients with acute st- segment elevation myocardial infarction. PLoS ONE, 9: e86959. 